Journal of Epidemiology and Public Health (2019), 4(3): 138-155

https://doi.org/10.26911/jepublichealth.2019.04.03.01

\title{
Determinants of Recurrence and Death in HIV-Malaria Co-Infection Patients in Jayapura, Papua, Indonesia
}

\author{
Dian Winiarti'), Ambar Mudigdo²), Bhisma Murti'1) \\ ${ }^{1)}$ Masters Program in Public Health, Universitas Sebelas Maret \\ ${ }^{2)}$ Faculty of Medicine, Universitas Sebelas Maret
}

\begin{abstract}
Background: Human Immunodeficiency Virus (HIV) is one of the important public health problems in the world which causes death of more than 35 million people annually. HIV infection is often associated with several comorbidities caused by the presence of endemic infectious diseases in certain regions, one of them is malaria. Analyzing the survival of HIV / AIDS patients malaria coinfection is based on risk factors for recurrence and death due to malaria. This study aimed to examine the determinants of recurrence and death in HIV-malaria co-infection patients in Jayapura, Papua, Indonesia.

Subjects and Method: This was a retrospective cohort study conducted in the VCT room at Dok II Regional General Hospital, Jayapura, Papua Province, Indonesia, from May to June 2018. A sample of 183 people living with HIV/AIDS (PLWH) was selected by fixed disease sampling. The dependent variable was recurrence. The independent variables were drug taking adherence, nutritional status, economic status, use of mosquito nets, spraying residues in the house, healthy hygiene behavior, co-infection with malaria. The data were obtained from medical record. The other data were collected by questionnaire. The data were analyzed using path analysis.

Results: The risk of recurrence in PLWH co-infected with malaria decreased with ARV treatment adherence $(\mathrm{b}=-2.17 ; 95 \% \mathrm{CI}=-3.24$ to $-1.09 ; \mathrm{p}<0.001)$ and compliance with Cotrimoxazole treatment $(>95 \%)(b=-1.88 ; 95 \% \mathrm{CI}=-2.58$ to $-1.19 ; \mathrm{p}<0.001)$. The risk of recurrence in PLWHA co-infected with malaria increased with low income $<\mathrm{Rp} 2,000,000(\mathrm{~b}=3.06 ; 95 \% \mathrm{CI}=2.04$ to 4.07; $\mathrm{p}<0.001)$, poor health behavior (mean $<5)(\mathrm{b}=1.66 ; 95 \% \mathrm{CI}=0.92$ to $2.40 ; \mathrm{p}<0.001)$, poor nutritional status $(b=2.10 ; 95 \% \mathrm{CI}=1.44$ to $2.76 ; \mathrm{p}<0.001)$, and did not use bed nets $(b=0.73 ; 95 \%$ $\mathrm{CI}=0.16$ to $1.29 ; \mathrm{p}=0.011)$. The risk of death in PLWHA coinfected with malaria decreased with ARV treatment adherence $(>95 \%)(b=-2.08 ; 95 \% \mathrm{CI}=-3.02$ to $-1.14 ; \mathrm{p}<0.001)$ and healthy behavior (mean $>5)(b=-1.43 ; 95 \% \mathrm{CI}=-2.15$ to $-0.70 ; \mathrm{p}<0.001)$. The risk of death in PLWHA coinfected with malaria increased with low income $(<\mathrm{Rp} 2,000,000)(\mathrm{b}=3.06$; $95 \% \mathrm{CI}=2.04$ to 4.07; $\mathrm{p}<0.001)$, poor health behavior (mean $<5)(\mathrm{b}=1.66$; $95 \% \mathrm{CI}=0.92$ to $2.40 ; \mathrm{p}<0.001)$, and poor nutritional status $(\mathrm{b}=2.10 ; 95 \% \mathrm{CI}=1.44$ to 2.76 ; $\mathrm{p}<0.001)$.

Conclusions: The risk of recurrence in PLWHA co-infected with malaria increases with low income, poor health behavior, and poor nutritional status, but decreases with adherence to ARV treatment and Cotrimoxazole treatment. The risk of death of PLWHA coinfected with malaria increases with low income, poor health behavior, and poor nutritional status, but decreases with adherence to ARV treatment.
\end{abstract}

Keywords: recurrence, co-infection, HIV/AIDS, malaria, death, path analysis, people with HIV/AIDS

\section{Correspondence:}

Dian Winiarti. Masters Program in Public Health. Universitas Sebelas Maret. Jl. Ir. Sutami 36A, Surakarta, Central Java 57126, Indonesia. Email: Dianwiniarti@gmail.com.

Mobile: +6281344266960

\section{BACKGROUND}

Human Immunodeficiency Virus (HIV) is still one of the essential problems of public health in the world which causes the death of more than 35 million people. Based on data from the World Health Organization 
(WHO), Sub-Saharan Africa is the region most affected with 25.6 million cases. 2016 deaths from AIDS in the world were 890,000 cases in adults and there were 120,000 cases in children aged $<15$ years (WHO, 2017). According to The Joint United Nations Program on HIV / AIDS (UNAIDS) Indonesia is the third largest country in Asia and the Pacific number of people living with HIV / AIDS (PLWHA) (UNAIDS, 2015).

Based on data from the Directorate General of P2P in the Indonesian Ministry of Health 2017, the cumulative number of AIDS sufferers by province from 1987 to December 2016 was 86,780 cases, with the third highest being East Java $(16,911)$, Papua $(13,398)$ and DKI Jakarta $(8,648)$, while the number of new HIV cases by province from 2014 to 2016 was 104,896 cases, with 41,250 highest cases in 2016 and the top three provinces including East Java $(6,513)$, DKI Jakarta $(6,019)$ and Papua $(3,866)$ (Health profile data and information Indonesia, 2016).

The spread of HIV, especially in Papua, is very fast. Data from the Papua Provincial Health Office up to May 2018 amounts to 35 thousand cases. The highest HIV/AIDS sufferers were in Nabire Regency with 6,500 cases, followed by Jayapura City with 6,007 cases, then Mimika Regency with 5,472 cases. (Papua Provincial Health Office, 2018). Surveillance sentinel for Sex Workers (WPS) reported 6.28\% of FSWs in Papua had HIV. The Integrated HIV and Behavior Survey (STPH) in Papua conducted by the Central Statistics Agency (BPS) reports that in the provinces of Papua and West Papua, the HIV epidemic tends to spread to $2.4 \%$ of the adult population of 15-49 years of productive age as many as 26,525 people (99.08\%) and reproductive age women amounting to 14,684 (54.9\%) (KPA of Papua and West
Papua Provinces, 2009) (Papua Provincial Health Office, 2018).

HIV infection is often associated with several comorbidities caused by the presence of endemic infectious diseases in certain regions, one of which is Malaria (Alemu et al., 2013). The eastern region of Indonesia, especially Papua, according to WHO, is categorized as a hyper-endemic area of malaria with API of more than $10 \%$ (national API <1\%) (Hanandita \& Tampubolon, 2016). Data from the Papua Provincial Health Office 2017 reported that there were 413,657 malaria cases in January to December 2016, with the most cases being> 15 years old 46,280 cases, the majority of them were male (Papua Provincial Health Office, 2017).

Malaria comorbidity and HIV / AIDS, have a significant effect on global health. Since 2009, the CDC has included malaria in the list of AIDS-related opportunistic infections (Saracino et al, 2012). The latest global load statistics show 207 million cases and 627,000 malaria deaths, most in Africa and Southeast Asia. The spread of HIV / AIDS and malaria in Papua which overlaps geographically, climate factors, and widespread epidemics allows for such co-infection (Alemu et al., 2013; Rattanapunya et al., 2013; Nasir et al., 2016).

Coinfection of HIV/AIDS with malaria is a burden on PLHIV because malaria recurrence affects the development of clinical symptoms by changing the function of the immune system. Cohort studies have shown that recurrence of malaria infection causes an increase in HIV viral load in the blood, even during asymptomatic parasitemia. HIV viral load returns to baseline eight weeks after acute malaria infection (Kublin et al., 2005) (Hochman and Kim, 2009). CD4 + T lymphocytes temporarily decrease during clinical malaria episodes in both HIV-infected and uninfected patients 
Journal of Epidemiology and Public Health (2019), 4(3): 138-155

https://doi.org/10.26911/jepublichealth.2019.04.03.01

(Geertruyden et al., 2006). Recurrence of recurrent Malaria infection associated with a decrease in $\mathrm{CD} 4+\mathrm{T}$ lymphocytes that is faster over time indicates that malaria can lead to faster disease progression from HIV to AIDS (Mermin et al., 2006). Coinfection of HIV / AIDS with malaria increases the mortality rate of PLWHA. (Korenromp et al., 2005).

ODHA at advanced levels who do not routinely consume ARVs can increase their risk of developing opportunistic infections and malaria (Kasirye et al., 2016). WHO recommends prophylactic treatment with Cotrimoxazole (CTX) in PLWHA who receive ARVs in areas of high malaria transmission intensity to reduce the risk of opportunistic infections (WHO, 2014). Other risk factors for coinfection of PLWH with malaria that relate to hosts with the environment include the use of InsecticideTreated Mosquito Net (ITN) for populations at risk of malaria in high-endemic areas and indoor residual spraying (IRS), namely the application of long-acting chemical insecticides to reduce the life span of mosquito vectors and to reduce mosquito vector density economic status, nutritional status, and Clean Healthy Life Behavior (PHBS) indirectly affect the coinfection of PLWHA and malaria (Rattanapunya et al, 2015; WHO, 2006).

Advanced HIV disease is still a significant challenge. Although access to treatment is affordable for antiretroviral therapy (ART) treatment and there is a decline in HIV-related deaths, there are still many PLHIV who die from opportunistic infection. The need to find better ways to identify and manage advanced HIV disease, to achieve global targets for reducing HIV deaths by $50 \%$ by 2020 . Health services must be adapted to reach and meet the needs of the most at risk populations, including implementing 'zero' policies. tolerance 'of stigma and discrimination in all health services, and communities that are fully involved as equal partners (WHO, 2017).

Eliminating malaria is also one of the top priorities for policy makers in Indonesia. The commitment of the Sustainable Development Goals (SDGs) in an effort to eradicate written malaria in the third objective is to ensure a healthy life and strive for prosperity for all, with specific objectives of ending the epidemic The survival time of PLHA infected with malaria to AIDS, tuberculosis, malaria and neglected diseases neglected-tropical up to 2030 (Infodatin malaria, 2016).

\section{SUBJECTS AND METHOD \\ 1. Study Design \\ This study was case-control study conduct- ed in VCT room of Dok II Hospital, Jaya- pura, Papua Province, Indonesia, from May to June 2018.}

\section{Population and Samples}

The source population used in this study were HIV/AIDS sufferers diagnosed with Malaria from 2015 who came to the Dok II Hospital, Jayapura, Papua. Samples of PLWH with malaria recurrence were 97 study subjects and PLWH groups with deaths of 86 subjects were selected by fixed disease sampling.

\section{Study Variables}

The dependent variables were survival and death. The independent variables were drug taking adherence, nutritional status, economic status, use of mosquito nets, spray residu, and healthy behavior.

\section{Operational Definition of Variables} Data on survival time of HIV/AIDS coinfected patients with Malaria who relapsed was the time of survival of PLWH with malaria co-infection. The survival time of HIV/AIDS patients co-infected with Mala- 
ria with death was the time of survival of PLHA-infected PLHIV to death.

Antiretroviral treatment adherence was defined as behavior to adhere to the suggestions or procedures of the doctor about the use of antiretrovirals, which were previously preceded by a consultation process between patients and doctors as medical service providers. Compliance with Cotrimoxazole prophylactic treatment was behavior to adhere to doctor's suggestions or procedures Cotrimoxazole prophylactic treatment in relapsing Malaria.

Nutritional status was the state of nutritional status of PLWH at the last visit which was calculated based on antopometric measurements of body weight per age (weight for age) measured by body mass Index (BMI).

Economic status was defined as the monthly income received by ODHA within one month. The use of insecticidal bed nets was the use of thin insecticidal blinds which provide protection against mosquitoes, flies and other insects. Spraying residues in the house was the application of insecticides to the inside of the residence, on the walls and other surfaces that function as a resting place for mosquitoes infected with malaria. Clean and healthy behavior was a set of behaviors practiced by the study subjects.

\section{Study Instruments}

The data were collected by medical record and questionnaire. The validity tests were conducted on 20 patients undergoing treatment at Dok II hospital, Jayapura, Papua, Indonesia. The results of reliability test included item total correlations $(\geq 0.20)$ and Cronbach's alpha $(\geq 0.70)$.

\section{Data Analysis}

The data analysis was carried out using path analysis. The steps of path analysis in including model specification, model identification, fit model, estimation, and model re-specification.

\section{Research Ethics}

The research ethics included informed consent, anonymity, confidentiality and ethical clearance. The ethical clearance was obtained from Dr. Moewardi hospital, Surakarta, Central Java.

\section{RESULTS \\ 1. Sample characteristics \\ A sample of 215 study subjects was selected for this study, with PLHIV groups accom- panied by 97 recurrences of malaria, which were not accompanied by recurrence of 118 people and PLHIV groups with 86 deaths, who lived 129 people.}

\begin{tabular}{lcc}
\multicolumn{3}{l}{ Table 1. Sample characteristics } \\
\hline Characteristics & n & \% \\
\hline Gender & & \\
Female & 121 & 56.3 \\
Male & 94 & 43.7 \\
Age (years) & & \\
1-14 & 2 & 0.09 \\
$15-19$ & 7 & 3.3 \\
$20-24$ & 36 & 16.7 \\
$25-49$ & 159 & 74 \\
$\geq 50$ & 11 & 5.1 \\
Marital Status & & \\
Single & 66 & 30.7 \\
Married & 120 & 55.8 \\
Divorced & 1 & 0.05 \\
Splitted & 13 & 6 \\
Widow/widower & 15 & 7 \\
Education & & \\
No education & 5 & 2.3 \\
Primary School & 15 & 7 \\
Junior High School & 31 & 14.4 \\
Senior High School & 125 & 58.1 \\
College & 39 & 18.1 \\
Occupation & & \\
Not working & 100 & 46.5 \\
Working & 115 & 53.5 \\
\hline
\end{tabular}

Table 1 showed that as many as 121 (56.3\%) study subjects were women. Most of the study subjects were at age 25-49 years (159 people, 74\%). Most of the study subjects were married (120, 55.8\%). As may as 125 study subjects (58.1\%) had high 
Journal of Epidemiology and Public Health (2019), 4(3): 138-155

https://doi.org/10.26911/jepublichealth.2019.04.03.01

education and 115 study subjects (53.5\%) were employed.

\section{Path Analysis}

Figure 1 depicted path model of Malaria coinfection recurrence with estimation. The number of measured variables were 7 , endogenous variables were 5 , and exogen- ous variables were 3 . Therefore, the value of degree of freedom (df) was 25 (over identified). Figure 2 depicted path model of death among PLWHA.

Table 2 showed the results of path analysis. Table 2 showed that

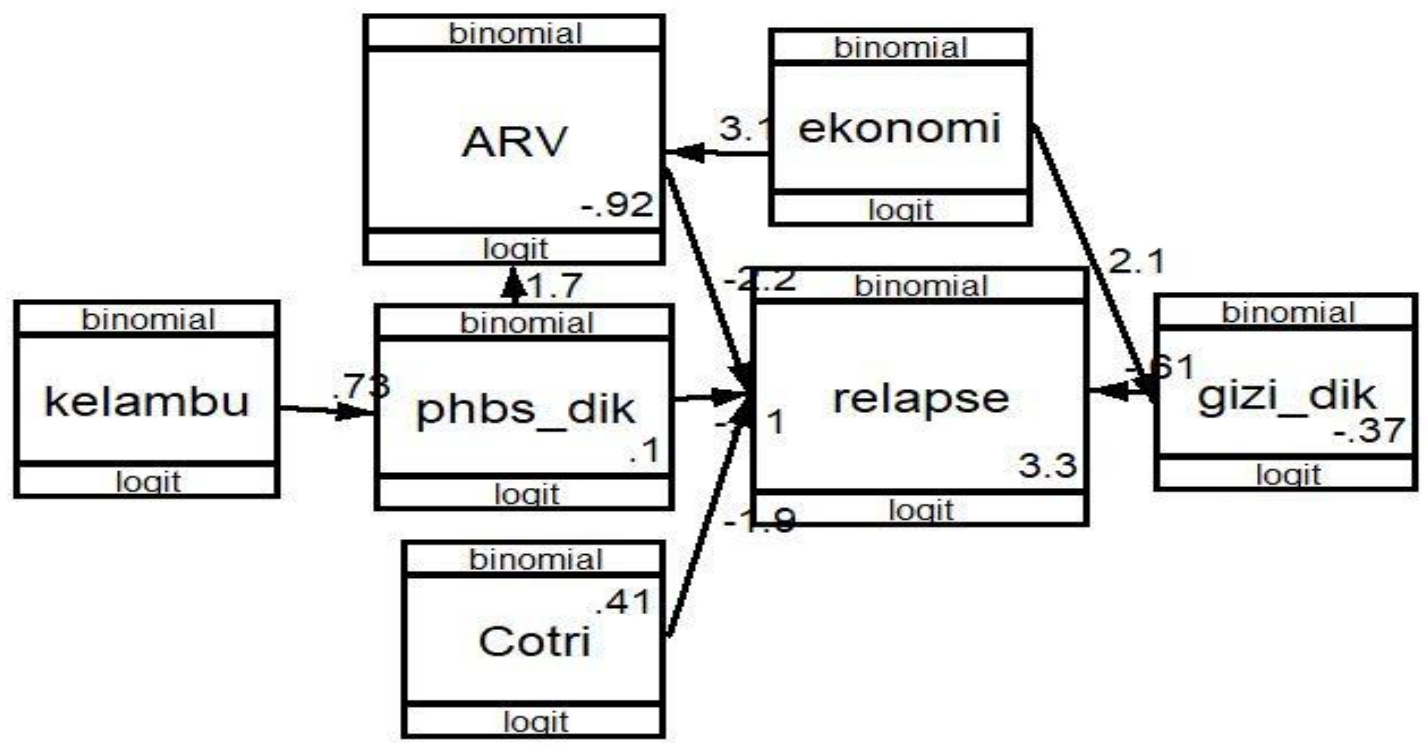

Figure 1. Path model of Malaria co-infection recurrence

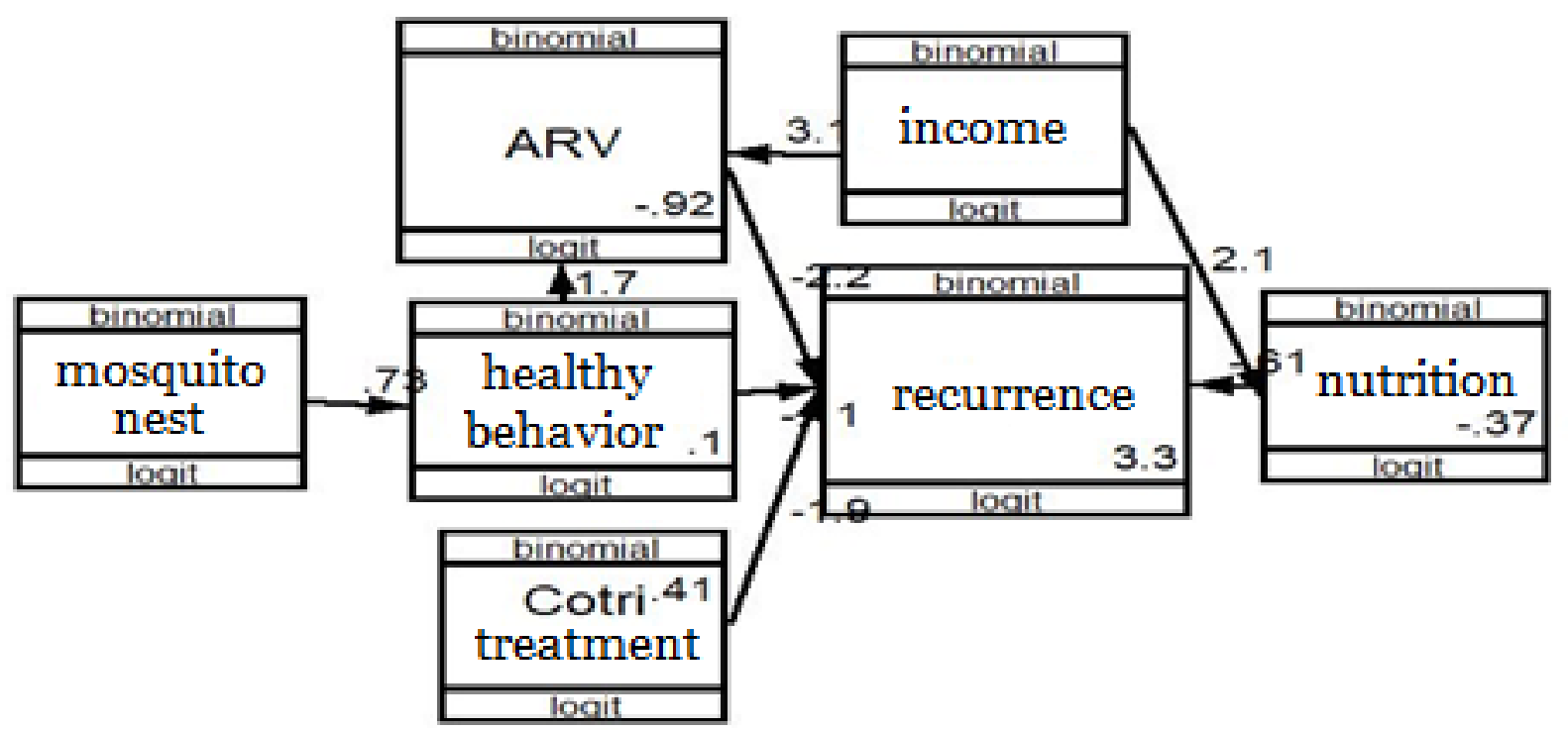

Figure 2. Path model of death among PLWHA 
Winiarti et al./ Determinants of Recurrence and Death in HIV-Malaria

Table 2. Results of path analysis on the determinants of co-infected malaria recurrence among PLWH

\begin{tabular}{|c|c|c|c|c|c|c|}
\hline \multirow[b]{2}{*}{ Dependent Variables } & \multirow{2}{*}{\multicolumn{2}{|c|}{ Independent variables }} & \multirow[b]{2}{*}{$\mathbf{b}$} & \multicolumn{2}{|c|}{ CI 95\% } & \multirow[b]{2}{*}{$\mathbf{p}$} \\
\hline & & & & $\begin{array}{c}\text { Lower } \\
\text { limit }\end{array}$ & $\begin{array}{c}\text { Upper } \\
\text { limit }\end{array}$ & \\
\hline \multicolumn{7}{|l|}{ Direct Effect } \\
\hline \multirow[t]{4}{*}{ Malaria recurrence } & $\leftarrow$ & ARV treatment adherence & -2.17 & -3.24 & -1.09 & $<0.001$ \\
\hline & $\leftarrow$ & Nutritional Status & -0.61 & -1.46 & -0.24 & 0.164 \\
\hline & $\leftarrow$ & Healthy behavior & -0.11 & -0.83 & -0.61 & 0.764 \\
\hline & $\leftarrow$ & Cotrimoxazole treatment & -1.88 & -2.58 & -1.19 & $<0.001$ \\
\hline \multicolumn{7}{|l|}{ Indirect Effect } \\
\hline \multirow[t]{2}{*}{ ARV treatment adherence } & $\leftarrow$ & Economical Status & 3.06 & 2.04 & 4.07 & $<0.001$ \\
\hline & $\leftarrow$ & Healthy behavior & 1.66 & 0.92 & 2.40 & $<0.001$ \\
\hline Nutritional Status & $\leftarrow$ & Income & 2.10 & 1.44 & 2.76 & $<0.001$ \\
\hline $\begin{array}{l}\text { Healthy behavior } \\
\text { n Observation }=215 \\
\text { Log Likelihood }=-460.55\end{array}$ & $\leftarrow$ & Mosquito net & 0.73 & 0.16 & 1.29 & 0.011 \\
\hline
\end{tabular}

There was a direct influence between adherence to ARV treatment for malaria recurrence in malaria-infected PLWH and was statistically significant. PLWH coinfected with malaria with high antiretroviral treatment adherence $(\geq 95 \%)$ had an average logistical recurrence of malaria 2.17 points compared to PLWH coinfected with malaria with low ARV treatment adherence $(<95 \%)(b=-2.17 ; 95 \% \mathrm{CI}=-$ 3.24 to $-1.09 ; \mathrm{p}<0.001)$.

The results of the path analysis show that there is a direct influence between nutritional status of malaria recurrence in PLH infected with malaria even though it is not statistically significant. PLWH coinfected with malaria with good nutritional status (BMI 18.5) had an average malaria recurrence log record -0.61 points compared to PLWH coinfected with malaria with poor nutritional status (BMI <18.5) $(\mathrm{b}=-0.61 ; 95 \% \mathrm{CI}=-1.46$ to $-0.24 ; \mathrm{p}=$ 0.164).

The results of path analysis showed that there was a direct influence between PHBS on malaria recurrence in PLWH coinfected with malaria and was statistically insignificant. PLWH co-infected with malaria with good healthy behavior had an average logistical recurrence of malaria - o.11 than PLWH coinfected with malaria with poor healthy behavior ( $\mathrm{b}=-0.11 ; 95 \%$ $\mathrm{CI}=-0.83$ to $-0.61 ; \mathrm{p}=0.764$ ).

The results of the path analysis showed that there was a direct influence between Cotri treatment adherence to malaria recurrence in PLWH coinfected with malaria and was statistically significant. PLWHA co-infected with malaria with good Cotri treatment adherence ( $\geq 95 \%)$ had an average logographic recurrence of malaria -1.88 points compared to PLWHA coinfected by malaria with poor compliance with Cotri treatment $(<95 \%)(b=-1.88$; 95\% CI $=-2.58$ to -1.19 ; $\mathrm{p}<0.001)$.

There was an indirect influence between economic status and malaria recurrence through adherence to ARV treatment and was statistically significant. PLWH coinfected with malaria with a low income $(<\operatorname{Rp} 2,000,000)$ had had higher risk to malaria recurrence 3.06 units compared to PLWH with high income ( $\mathrm{Rp} 2,000,000)$ $(b=3.06 ; 95 \% \mathrm{CI}=2.04$ to 4.07 ; $\mathrm{p}<0.001)$.

The results of path analysis showed that there was an indirect effect between PHBS and malaria recurrence through adherence to ARV treatment and was statistically significant. PLWH poor healthy behavior had higher risk to malaria co- 
infected by 1.66 units compared to PLWH with good healthy behavior $(b=1.66 ; 95 \%$ $\mathrm{CI}=0.92$ to $2.40 ; \mathrm{p}<0.001$ ).

There was an indirect effect between income and malaria recurrence through

Table 3. The result of path analysis on the determinants of death among PLWH with co-infected malaria

\begin{tabular}{|c|c|c|c|c|c|c|}
\hline \multirow[b]{2}{*}{ Dependent variables } & & \multirow{2}{*}{$\begin{array}{l}\text { Independent } \\
\text { variables }\end{array}$} & \multirow[b]{2}{*}{$\mathbf{b}$} & \multicolumn{2}{|c|}{ 95\% CI } & \multirow[b]{2}{*}{$\mathbf{p}$} \\
\hline & & & & $\begin{array}{l}\text { Lower } \\
\text { limit }\end{array}$ & $\begin{array}{c}\text { Upper } \\
\text { limit }\end{array}$ & \\
\hline \multicolumn{7}{|l|}{ Direct Effect } \\
\hline \multirow[t]{4}{*}{ Malaria Death } & $\leftarrow$ & $\begin{array}{l}\text { ARV treatment } \\
\text { adherence }\end{array}$ & -2.08 & -3.02 & -1.14 & $<0.001$ \\
\hline & $\leftarrow$ & Nutritional Status & -0.41 & -1.29 & 0.47 & 0.366 \\
\hline & $\leftarrow$ & Healthy behavior & -1.43 & -2.15 & -0.70 & $<0.001$ \\
\hline & $\leftarrow$ & $\begin{array}{l}\text { Cotri treatment } \\
\text { adherence }\end{array}$ & 0.11 & -0.58 & 0.79 & 0.760 \\
\hline \multicolumn{7}{|l|}{ Indirect Effect } \\
\hline \multirow[t]{2}{*}{ ARV treatment adherence } & $\leftarrow$ & Economy status & 3.06 & 2.04 & 4.07 & $<0.001$ \\
\hline & $\leftarrow$ & Healthy behavior & 1.66 & 0.92 & 2.40 & $<0.001$ \\
\hline Nutritional Status & $\leftarrow$ & Economy status & 2.10 & 1.44 & 2.76 & $<0.001$ \\
\hline $\begin{array}{l}\text { PHBS } \\
\text { n Observation= } 215 \\
\text { Log Likelihood }=-456.10\end{array}$ & $\leftarrow$ & Mosquito net & 0.73 & 0.16 & 1.29 & 0.011 \\
\hline
\end{tabular}

The risk of death in PLWH coinfected with malaria decreased with ARV treatment adherence $(>95 \%)(\mathrm{b}=-2.08$; $95 \% \mathrm{CI}=-3.02$ to $-1.14 ; \mathrm{p}<0.001)$ and healthy behavior (mean> 5) $(b=-1.43$; 95\% $\mathrm{CI}=-2.15$ to $-0.70 ; \mathrm{p}<0.001)$. The risk of death in PLWHA co-infected with malaria increased with income $(<\mathrm{Rp} 2,000,000)$ $(\mathrm{b}=3.06 ; 95 \% \mathrm{CI}=2.04$ to 4.07 ; $\mathrm{p}<0.001)$, poor health behavior (mean $<5)(b=1.66$; $95 \% \mathrm{CI}=0.92$ to $2.40 ; \mathrm{p}<0.001)$, and poor nutritional status $(\mathrm{b}=2.10 ; 95 \% \mathrm{CI}=1.44$ to 2.76 ; $\mathrm{p}<0.001$ ).

\section{DISCUSSIONS}

\section{The effect of ARV adherence on malaria recurrence}

The result of this study showed that there was an effect of ARV treatment adherence on malaria recurrence. This was in line with Kasirye et al. (2017) which stated that ARV has an effect in decreasing malaria recur- nutritional status and it was statistically significant. There was an indirect effect between the use bed nets and malaria recurrence through healthy behavior. 
cation of the HIV virus, so that it increased the viral load (Foca et al., 2012).

\section{The effect of Cotrimoxazole treat- ment adherence on malaria recur- rence}

The result of this study showed that there was an effect of CTX treatment adherence on malaria recurrence. This study was in line with a study done by Kasirye et al. (2017) which stated that CTX prophylactic treatment has an effect on reducing malaria recurrence. The Randomized Trial study conducted by Bwakura-Dangarembizi et al. (2014) showed that PLWHA with CTX prophylaxis showed low bacterial infection, which prevented parasitemia and clinical malaria.

Polyak et al. (2016) reported that Prophylactic treatment of CTX in PLWHA who lived in malaria endemic areas can reduce the occurrence of malaria recurrence.

Cotrimoxazol (CTX) was an antimicrobial drug containing a fixed dose combination of sulphamethoxazole and trimethoprim which commonly used in Sub-Saharan Africa because of its low cost, wide availability, and broad-spectrum antimicrobial activity. The combination of these drugs produced a synergistic effect on various bacterial and protozoan infections. UNAIDS and WHO recommended the prophylactic treatment of CTX for opportunistic infections in groups of individuals who were infected by HIV, especially children and first trimester pregnant women. CTX has been shown to decrease malaria morbidity in HIV-infected populations (WHO, 2005, Bwakura-Dangarembizi, et al., 2014, Jegede et al., 2017).

\section{The effect of nutritional status on malaria recurrence}

The result of this study showed that there was an effect of nutritional status on malaria recurrence. This study was in line with a study done by Koethe and Heimburger (2010) which stated that BMI was a significant prognostic factor in HIV infection. Decreased energy intake due to gastrointestinal tract infections was considered the main cause of weight loss in people who were infected by HIV. In addition, an enhancement in proinflammatory cytokines in untreated HIV infections prevented weight gain despite adequate energy and protein intake. Individuals with low BMI can significantly increase HIV-1 viral load and contribute to anemia and decreased functional capacity.

Individuals at every level of HIV disease, especially from the lower socioeconomic strata, were at risk of nutritional deficiencies, and nutritional status was a strong predictor of disease progression, survival, and functional status during the course of the disease (Swaminathan et al., 2008).

\section{The effect of healthy behavior on malaria recurrence}

The result of this study showed that there was an effect of healthy behavior on malaria recurrence. This study was in line with a study by Imbahale et al., (2010) which stated that poor sanitation condition was a potential source of disease.

A qualitative study by Makoge et al (2017) showed that public perception of malaria and typhoid was related to poverty because it was closely related to environmental sanitation around them. Malaria infection was associated with poverty, poor hygiene, and tropical climate conditions that were conducive for mosquitoes to breed.

The results of a study by Musoke et al (2013) indicated that an integrated approach to malaria prevention and vector control at the household level was highly important, in addition to environmental sanitation problems that affected malaria 
Journal of Epidemiology and Public Health (2019), 4(3): 138-155

https://doi.org/10.26911/jepublichealth.2019.04.03.01

transmission, it should be recommended for health promotion for high risk groups, household responsibilities and the importance of community leaders to further explore the impact of public health from an integrated approach to malaria prevention.

\section{The effect of income on malaria recurrence}

The result of this study showed that there was an indirect effect of economy status on malaria recurrence through ARV treatment adherence and it was statistically significant. This study was in line with a study by Lowassa et al. (2012) which showed thatthe farther the distance of the health facility, the higher the cost for an individual to visit a health facility. Quantitative research done by Poudal et al. (2017) concluded that HIV/AIDS significantly increased the economic burden, and poverty was an important factor in the transmission of HIV/AIDS, the lack of economic independence for PLWHA because of limited work skills made PLWHA more vulnerable in many ways, including exposure to high-risk behavior and difficult access to health care services.

\section{The effect of healthy behavior on} ARV treatment adherence

The result of this study showed that there was an indirect effect of healthy behavior on malaria recurrence through ARV treatment adherence and it was statistically significant. A study done by Kahn et al. (2012) showed thatIntegrated Prevention Campaign (IPC) programprovided health education, HIV test and counseling, water filters, insecticide-treated nets, condoms, and for calculating CD4 total of HIVinfected people, 3 months of cotrimoxazole, and referral for treatment. This can predict disability-adjusted life years (DALY's), including the use of ARV. Early treatment of HIV produced additional DALY, therefore, it reduced the access to health facili- ties and the costs would be more economical.

WHO (2010) released a water sanitation and hygiene (WASH) program. In a small amount of developing literature that has demonstrated the importance of WASH programs in reducing the impact of HIV/ AIDS on PLWHA, the immune system of vulnerable PLWHA made them more susceptible to opportunistic infections.

\section{The effect of income on nutritional status}

The result of this study showed that there was an indirect effect of income on malaria recurrence through nutritional status and it was statistically significant. This study was in line with a study by Sunguya et al. (2017) which showed that PLWHA with good economic status was associated with good nutritional status. A study by Weiser et al. (2011) stated that economic status influenced food insecurity in PLWHA who lived in areas of high poverty such as sub-Saharan Africa. Food insecurity has consequences for mental health, such as depression and increased drug abuse, which contributed to the risk of HIV transmission and the risk of developing opportunistic infections. Increased risky sexual practices, non-compliance with antiretroviral therapy, visits to clinics that were not on schedule and even disconnected treatment were strong determinants of poor HIV health outcomes. Therefore, PLWHA who lived in malaria endemic areas would have high risk of recurrence.

\section{The effect of the use of mosquito nest on healthy behavior}

The result of this study showed that there was an indirect effect of the use of mosquito on malaria recurrence through healthy behavior and it was statistically significant. WHO (2008) recommendations on Priority Interventions: HIV/AIDS prevention, treatment, and care in the health sector stated that the use of the use of mosquito nest was 
included in environmental interventions which recommended for PLWHA who lived in malaria endemic areas.

\section{The effect of ARV treatment adhe- rence on death}

The result of this study showed that there was an effect of ARV treatment adherence on death in malaria co-infection PLWHA which was statistically significant. WHO (2015) in Guidelines on when to start ART and on pre-Exposure for HIV stated that since 2013, based on scientific evidence and existing programs, early initiation of ART reduced mortality, morbidity, and HIV transmission. One entry inhibitors prevented HIV attachment to the target cell surface (positive CD4 lymphocytes and various other cells). Nonnucleosides and nucleoside/ nucleotide reverse transcriptase inhibitors (NNRTIs and NRTIs) prevent the production of multiple brands of DNA from RNA virus, while integrase inhibitors block transfer and incorporate of DNA virus into the host cell genome. Protease inhibitors (PIs) prevent the assembly of new HIV particles. The goal of therapy was to build a regimen that allowed maximum suppression and resistance to HIV replication.

\section{The effect of Cotrimoxazole treat- ment adherence on death}

The result of this study showed that there was a direct effect of Cotri treatment adherence on death in malaria co-infection PLWHA which was statistically non-significant. A systematic review sudy by Hassani et al. (2015) stated that there was a relationship between CTX prophylaxis and the number of $\mathrm{CD} 4$ cell at the beginning of ART treatment. However, there was no statistically significant association between CTX prophylaxis and survival in a subgroup of people with $\mathrm{CD} 4$ total above 200 cells per microliter and stage 1 or 2 HIV according to WHO . It showed that research subjects were more likely to survive when they received CTX prophylaxis with the total of CD4 when they started ART (36\% reduction in mortality).

\section{The effect of nutritional status on death among PLWH with malaria co-infection}

The result of this study showed that there was an effect of nutritional status on death in malaria co-infection PLWHA. A study by Thiebaut et al. (2000) stated that BMI at the beginning of treatment was not a disease predictor, but in developed countries, low BMI was a predictor of mortality and morbidity in HIV-infected patients.

A study by Koethe and Heimburger (2010) showed that there was an inverse relationship between progression of HIV disease and BMI. Cohort study on HIV-1infected drug users in the United States showed that obesity was associated with slower disease progression and better survival, regardless of $\mathrm{CD}_{4}+$ total lymphocyte.

Study of Koethe et al. (2010) illustrated the relationship between early weight gain at the time of initiation of ART. A study in Zambia which involved 27,915 patients who survived for $>6$ months on ART showed an inverse relationship between early weight gain and the risk of mortality after 6 months of treatment. Weight gain after starting ART was associated with increased survival and a reduced risk of clinical failure, especially in lower BMI strata. Prospective trials to increase body weight after starting ART among patients with malnutrition in resource-limited settings were justified.

\section{The effect of healthy behavior on death}

The result of this study showed that there was an effect of PHBS on death in malaria co-infection PLWHA. WHO (2006) stated that about 42\% (30- 53\%) from global malaria burden, or half a million deaths per 
Journal of Epidemiology and Public Health (2019), 4(3): 138-155

https://doi.org/10.26911/jepublichealth.2019.04.03.01

year, it can be prevented by environmental management, to reduce the burden of malaria according to the type of environment (i.e. wilderness and hills, rural, urban, and periurban). Environmental differences affects the behavior of Anopheles species (biting and resting behavior), and by the number and characteristics of their breeding sites so that it was easier for vector control. Other ways to control malaria included water management (intermittent irrigation or wet and dry alternatives; sprinklers, drops or central pivot irrigation); vegetation management in rural environments; safe practices for storing domestic water; management of solid waste in and around urban environments; and maintenance of water and sanitation supplies in urban areas.

\section{The effect of income on ARV treatment adherence}

The result of this study showed that there was an indirect effect of economy status on death in malaria co-infection PLWHA through ARV treatment adherence which was statistically insignificant. A descriptive qualitative study conducted by Azia et al (2016) stated thatEconomic factors which identified to reduce the adherence to use ART included poverty, unemployment, and insufficient money for transportation.

A study of Li et al., (2010) showed that having easy access to treatment was associated with better adherence to ART. Easy access to health facilities can measure whether PLWHA make regular visits to doctors, or they have knowledge of how and where to access ARV. This was also an evidence of the positive role of the health providers during ART.

\section{The effect of healthy behavior on} ARV treatment adherence

The result of this study showed that there was an indirect effect of PHBS on death in malaria co-infection PLWHA through ARV treatment adherence which was statistically insignificant. The result of this study was in accordance with Fisher theory, which was IMB Model of ART Adherence (2010). According to Fisher (2010),behavioral skills affected the level of adherence to take medication for people living with HIV both directly and indirectly. These behavioral skills included the skills to obtain and manage ARV therapy on their own, to minimize side effects, to renew adherence in ARV therapy as needed, to obtain social support and instrumental to support adherence, and as self-reinforcement to obey from time to time.

The result of this study was in line with a study by Horvath et al. (2015) in 312 PLWHA, the result of this study showed that healthy behavioral skills directly influenced the adherence to take ARV drugs in PLWHA. Horvath explained that PLWHA who have good health behavior skills have relevant information and sufficient motivation to make them obedient in taking ARV drugs and vice versa.

Amico (2011) stated that someone's healthy behavior skills directly influenced the adherence to take ARV drugs in PLWHA.

Behavior that is balanced with sufficient knowledge and was a long-standing and repetitive habit of clean and healthy life could influence the adherence to take ARV drugs, based on attitudes and behaviors about the importance of being healthy. The habits of PHBS behavior and awareness of the importance of being healthy were supporting factors for ARV treatment adherence.

\section{The effect of income on nutri- tional status}

The result of this study showed that there was an effect of economy status on death through nutritional status. This was in line with a statement of Laftah(2014) which 
stated that the more severe the clinical manifestations, the higher the clinical stage of the patient. Normal CD4 total was $410-$ 1490 cells $/ \mathrm{mm} 3$. Clinical stage indirectly affected $\mathrm{CD} 4$ cell total, which was by interfering the nutrient intake so that patients have poor nutritional status due to opportunistic infections. This was also confirmed by the results of the study conducted by Payam et al., (2016) which showed that viruses in large numbers could lead to decreased ability and host power to suppress damage to $\mathrm{CD} 4$ cells so that the cells became quickly run out (immunosuppression).

Regular consumption of antiretrovirals in accordance with the instructions of health personnels would inhibit the course of HIV disease, increased CD4 counts, reduced the amount of virus in the blood, and felt better so that it increased the appetite. This was in accordance with the results of the study of Mariz et al (2011) which stated that the status of patients who took antiretroviral drugs was statistically significant with poor nutritional status in HIV/AIDS patients.

Economic status has a major influence on the success of HIV treatment because it can have an impact on the nutritional intake consumed by PLWHA. The higher the economic status a person, the higher the nutritional intake that was consumed by a person, the higher the economic status, the higher the awareness of a person to live healthier with adequate nutrition. Conversely, someone with a low economic status would only consume food which in accordance with his/her purchasing power, which inhibit the fulfillment of better nutritional intake that must be consumed by PLWHA.

\section{The effect of mosquito nest on healthy behaviour}

The result of this study showed that there was an effect of ITN (Insectiside Treated Net) on death through PHBS. . The result of this study was in accordance witha study in Trenggalek which showed that there was a strong correlation between PHBS, home construction and the incidence of malaria because all respondents' houses did not have gauze and ceilings to prevent mosquitoes from entering the house (Yudhastuti, 2008). A hole that was not covered with gauze would cause an increase in the mosquito population in the house (Sintasath et al., 2015; Ye et al., 2017).

The physical condition of community houses was generally very simple because it was made of materials such as boards or bamboo so that the holes were found in the walls of the house. The holes were not fitted with the gauze, so that mosquitoes can freely enter the house and attack the people. Cleanliness of the house, both inside and outside was also not maintained. Many tools were scattered, disorganized, dirty, and stuffy inside the house, which made the mosquitoes to stay in the house.

There were stacks of used goods and garbage around the house. There were also puddles of water, bushes, and wild plants. Overall, the physical condition of community houses both inside and outside the house was the cause of malaria in the Sentani Lake area.

\section{REFERENCES}

Achappa B, Madi D, Unnikrishnan B, Ramapuram JT, Rao S, Mahalingam S (2013). Adherence to retroviral therapy among people living with HIV. N Am J Med Sci, 5(3), 220-223. doi: 10.4103/1947-2714.109196

Adler MW, Edwards SG, Miller RF, Sethi G, Williams I (2012). The ABC of HIV 
Journal of Epidemiology and Public Health (2019), 4(3): 138-155

https://doi.org/10.26911/jepublichealth.2019.04.03.01

and AIDS. West Sussex: Blackwell Publishing Ltd.

Agbelusi GA, Eweka OM, Umeizudike KA, Okoh M (2013). Current Perspectives in HIV Infection: Oral Manifestations of HIV. Nigeria: INTECH. Retrieved from http://dx.doi.org/10.5772/52941.

Alemayehu G, Melaku Z, Abreha T, Alemayehu B, Girma S, Tadesse Y (2015). Burden of malaria among adult patients attending general medical outpatient department and HIV care and treatment clinics in Oromia, Ethiopia: a comparative cross-sectional study. Malaria Journal, 1-11. Retrieved from https://doi.org/10.1186/s12936-0151029-0.

Alemu A, Shiferaw Y, Addis Z, Mathewos B, Birhan W (2013). Effect of malaria on HIV/AIDS transmission and progression. Parasites \& Vectors, 6: 18-26. doi: 10.1186/1756-3305-6-18.

Antsey NM, Russel B, Yeo TW, Price R (2009). The Pathophysiology of vivax malaria. Trends in Parasitology, 25 (5): 220-227. doi: 10.1016/j.pt.2009.02.003 .

Azia IN, Mukumbang FC, van Wyk B (2016). Barriers to adherence to antiretroviral treatment in a regional hospital in Vredenburg, Western Cape, South Africa. Southern African journal of HIV medicine, 17(1): 476. doi: 10.4102/sajhivmed.v17i1.476.

Babiker AG, Peto T, Porter K, Walker AS, Darbyshire JH (2001). Age as a determinant of survival in HIV Infection. Journal of Clinical Epidemiology, 54(12): 16-21. Retrieved from https://doi.org/10.1016/So895-4356(01)00456-5.

Baggaley RF, Hollingsworth TD (2015). Brief report: HIV-1 transmissions during asymptomatic infection: Ex- ploring the impact of changes in HIV1 viral load due to coinfections. $J$ Acquir Immune Defic Syndr, 68(5), 594-598. doi: 10.1097/QAI.0000000000000511.

Barcus MJ, Basri H, Picarima H, Manyakori C, Sekartuti, Elyazar I, Baird JK (2007). Demographic risk factors for severe and fatal vivax and falciparum malaria among hospital admissions in northeastern Indonesian Papua. Am J Trop Med Hyg, 77(5): 984-991. doi: PMID: 17984364.

Butt L, Morin J, Numbery G, Peyon I, Goo A (2010). Stigma HIV/AIDS di Wilayah Pegunungan Papua. Kerjasama antara Pusat Studi Kependudukan, UNCEN dan University of Victoria, Canada, 2010. Retrieved from papuaweb.org/dlib/tema/hiv-aids/butt-morin-etal-2010-stigma-HIV-id.pdf

Bwakura-Dangarembizi M, Kendall L, Bakeera-Kitaka S, Nahirya-Ntege P, Keishanyu R, Nathoo K (2014). A Randomized Tiral of Prolonged Co-trimoxazole in HIV infected Children in Africa. N Engl J Med, 370(1), 41-53. doi:10.1056/NEJMoa1214901.

ChangCC, Crane M, Zhou J, Min M, Cameron BA (2013). HIV and Co-infections. Immunological Reviews, 254(1), 114-142. doi:10.111/imr.12063

Chi BH, Yiannoutsos CT, Westfall AO, Newman JE, Zhou J, Cesar C, Brinkhof MW, Mwango A, Balestre E, Carriquiry G, Sirisanthana T, Mukumbi H, Martin JN, Grimsrud A, Bacon M, Thiebaut R, International Epidemiologic Databases to Evaluate AIDS Collaboration (2011). Universal definition of loss to follow-up in HIV treatment programs: a statistical analysis of 111 facilities in Africa, Asia, and Latin America. PLoS medicine, 8(10), e1001111. 
Cohen MS, Gay CL, Busch MP, Hecht FM (2010). The Detection of Acute HIV infection. The Journal of Infectious Disease, 202(2), 270-277. doi: 10.10$86 / 655651$

Cuadros DF, Branscum AJ, Crowley PH (2011). Hiv-malaria co-infection: effects of malaria on the prevalence of HIV in East sub-Saharan Africa. International Journal of Epidemiology, 40(4), 931-939. https://doi.org/10.1093/ije/dyq256.

Data dan Informasi Profil Kesehatan Indonesia. (2016). Data dan Informasi Profil Kesehatan Indonesia. Jakarta: Kementerian Kesehatan Republik Indonesia.

Edward C, Klatt M (2016). Pathology of HIV/AIDS. Savannah, United States of America: Mercer University School of Medicine.

Ekwaru JP, Campbell J, Malamba S, Moore DM, Were W, Mermin J (2013). The effect of opportunistic illness on HIV RNA viral load and CD4+ T cell count among HIV-positive adults taking antiretroviral therapy. J Int AIDS Soc, 16(1), 17355. doi: 10.7448/IAS.16.1.17355 .

Eric JA, Daria JH (2012). HIV-1 Antiretroviral Drug Therapy. Cold Spring Harbor Perspectives in Medicine, 2(4), ao07161. doi:10.1101/cshperspect.a007161

Ernawatiningsih NP, Purhadi (2012). Analisis survival dengan model regresi cox, study kasus: Pasien demam berdarah dengue di RS Haji Surabaya. Matematika, 2(2), 1693-1394. doi: https://doi.org/10.24843/JMAT.2012 .v02.io2.p26.

EuroCoord TO (2012). CD4 Cell Count and the Risk of AIDS or Death in HIVInfected Adults on Combination Antiretroviral Therapy with a Suppressed
Viral Load: A Longitudinal Cohort Study from COHERE. PLoS Med, 9(3), e1001194. https://doi.org/10.1371/journal.pmed.1001194.

Foca E, Odolini S, Brianese N, Carosi G (2012). Malaria and HIV in adults: when the parasite runs into the virus. Mediterr J Hematol Infect Dis, 4(1), e2012032. doi:10.4084/MJHID.2012.032.

German Advisory Committee Blood (Arbeitskreis Blut) S (2016). Human Immunodeficiency Virus (HIV). Transfusion Medicine and Hemotherapy, 43: 203222. doi:10.1159/000445852.

Hanandita W, Tampubolon G (2016). Geography and social distribution of malaria in Indonesian Papua: a crosssectional study. International Journal of Health Geographics, 15: 13-28. doi: 10.1186/s12942-016-0043-y

Handajani YS, Djoerban Z, Irawan $\mathrm{H}$ (2012). Quality of life people living with HIV/AIDS: Outpatient in Kramat 128 Hospital Jakarta. Acta Medica Indonesiana, 44(4), 310-316.

Hariasturi NI, Wibowo HA, Adam K, Subangkit, Kipuw NL, Roselinda (2016). Potensi Resistensi Virus HIV-1 terhadap Terapi Anti Retroviral (ART) pada Pasien Voluntary Conseling and Testing di beberapa Kota di Indonesia. Media Litbangkes, 26(3), 151156.

Kementrian Kesehatan RI (2016a). Program Pengendalian HIV/AIDS dan PIMS di fasilitas kesehatan tingkat pertama. Jakarta.

(2016b). Laporan Situasi perkembangan HIV-AIDS dan PMS di Indonesia April-Juni 2016. Ditjen P2P. Jakarta.

Saadani Hassani A, Marston BJ, Kaplan JE (2015). Assessment of the impact of cotrimoxazole prophylaxis on key 
Journal of Epidemiology and Public Health (2019), 4(3): 138-155

https://doi.org/10.26911/jepublichealth.2019.04.03.01

outcomes among HIV-infected adults in low- and middle-income countries: a systematic review. Journal of acquired immune deficiency syndrome, 3(3): S257-69.

Hochman S, Kim K (2009). The Impact of HIV and Malaria Coinfection: What Is Known and Suggested Venues for Further Study. Interdisciplinary Perspectives on Infectious Diseases, 1-8. http://dx.doi.org/10.1155/2009/617954

Imbahale SS, Filinger U, Githeko A, Mukabana WR, Takken W (2010). An exploratory survey of malaria prevalence and people's knowledge, attitudes and practices of mosquito larval source management for malaria control in western Kenya. Acta Tropica, 115, 248-256. doi: 10.1016/j.actatropica.2010.04.005

InfoDATIN (2014). Situasi dan Analisis HIV AIDS. Jakarta: Kementerian Kesehatan Republik Indonesia.

Jegede FE, Oyeyi TI, Abdulrahman SA, Mbah HA, Badru T, Agbakwuru C, Adedokun O (2017). Effect of HIV and malaria parasites co-infection on immune-hematological profiles among patients attending anti-retroviral treatment (ART) Clinic in Infectious Disease Hospital Kano, Nigeria. PLoS ONE, 12(3), e0174233. Retrieved from https://doi.org/10.1371/journal.pone. 0174233

Johnbull OS, Uche AP, Keisiena AJ, Francis FA, Oyemocho A (2014). Prevalence and risk factors of malaria in HIVinfected pregnant women on antiretroviral therapy in Enugu, Sout East Nigeria. AIDS \& Clinical Research, 5, 321-327. doi:10.4172/2155-6113.1000321.

Kahn JG, Muraguri N, Harris B, Lugada E, Clasen T, Grabowsky M et al. (2012).
Integrated HIV Testing, Malaria, and Diarrhea Prevention Campaign in Kenya: Modeled Health Impact and Cost-Effectiveness. PLos One, 7(2), e31316. doi: 10.1371/journal.pone.oo31316.

Kakisingi C, Mukuku O, Manika M, Mutombo A, Kasamba E, Tshikuluila B et al. (2016). Immunological, virological, parasitic and biological profile of malaria/HIV Co-infection in 18 years old and above patients in Lubumbashi (DR Congo). Open Access Library Journal, 3, e2647. Retrieved from http://dx.doi.org/10.4236/oalib.1102 647.

Kasirye RP, Baisley K, Munderi P, Levin J, Anywaine Z, Nunn A et al. (2016). Incidence of malaria by Cotrimoxazole use in HIV-infected Ugandan Adults on Antiretroviral Therapy: a Randomised, Placebo-controlled Study. AIDS, 30, 635-643. doi: 10.1097/QAD.0000000000000956.

Kasirye RP, Grosskurth H, Munderi P, Levin J, Anywaine Z, Nunn A et al. (2017). Effect of antiretroviral therapy on malaria incidence in HIV-infected Ugandan adults. AIDS, 31(4): 577582. doi: 10.1097/QAD.ooooooooo0001344 .

Klatt EC (2016). Pathology of AIDS. Savannah: Edward C. Klatt, MD.

Kleinbaum DG, Klein M (2005). Survival Analysis: A Self Learning Text. New York: Springer.

Koethe JR, Heimburger DC (2010). Nutritional Aspects of HIV-associated wasting in sub-Saharan Africa. The Amerian Journal of Clinical Nutrition, 91(4), 1138S-1142S. doi:10.3945/ajcn.2010.28608D.

Korenromp EL, Williams BGde Vlast SJ, Gouws E, Gilks CF, Ghys PD, Nahlen BL (2005). Malaria Attributable to the 
HIV-1 Epidemic, Sub-Saharan Africa. Emerging Infectious Disease, 11(9), 1410-1419. Retrieved from https://dx.doi.org/10.3201/eid1109.050337

Kublin JG, Patnaik P, Jere CS, Miller WC, Hoffman IF, Chimbiya N (2005). Effect of Plasmodium falciparum malaria on concentration of HIV-1RNA in the blood of adults in rural Malawi: a prospective cohort study. The Lancet, 365(9455), 233-240.

Li L, Lee SJ, Wen Y, Lin C, Wan D, Jiraphongsa C (2010). Antiretroviral therapy adherence among patients living with HIV/AIDS in Thailand. Nursing \& health sciences, 12(2), 212-20.

Lelliot PM, Mcmorran BJ, Foote SJ, Gaetan $B$ (2015). The influence of host genetics on erythrocytes and malaria infection: is there therapeutic potential? Malaria Journal, 289. Retrieved from https://doi.org/10.1186/s12936-0150809-x.

Lowassa A, Mazigo HD, Mahande AM, Mwang'onde BJ, Msangi S, Mahande MJ (2012). Social economic factors and malaria transmission in Lower Moshi, Northern Tanzania. Parasites and Vectors, 5, 129. Retrieved from https://doi.org/10.1186/1756-3305-5129

Makoge V, Maat H, Vaandrager L, Koelen

$M$ (2017). Health-seeking behaviour towards poverty-related disease (PRDs): A Qualitative study of people living in camps and on campuses in Cameroon. Plos Neglected Tropical Disease, 11(1), eoo05218. Retrieved from https://doi.org/10.1371/journal.pntd.ooo5218.

Mermin J, Ekwaru JP, Liechty CA, Were W, Downing R, Ransom R (2006). Effect of co-trimoxazole prophylaxis, antiretroviral therapy, and insectisidetreated bednets on the frequency of malaria in HIV-1 infected adults in Uganda: a prospective cohort study. The Lancet, 367(9518), 1256-1261.

Musoke D, Karani G, Ssempebwa JC, Musoke MB (2013). Integrated approach to malaria prevention at household level in rural communities in Uganda: experiences from a pilot project. Malaria Journal, 12: 327 . https://doi.org/10.1186/1475-287512-327.

Nasir IA, Agbede OO, Bakare M, Musa M, Babandina (2016). Severe malaria parasitaemia and its effects on hemoglobin and CD4+ cells of HIV Infected Pregnant Women at Kaduna State, Nigeria. Asian Pacific Journal of Tropical Disease, 6(12): 943-945. https://doi.org/10.1016/S2222-1808(16)61161-1

Njunda AL, Njumkeng C, Nsagha SD, Assob JC, Kwenti TE (2016). The prevalence of malaria in people living with HIV in Yaounde, Cameroon. BMC Public Health, 16, 964-971. doi: 10.1186/s12889-016-3647-z.

Nsanzabana C, Rosenthal PJ (2011). In vitro activity of antiretroviral drugs againts plasmodium falciparum. Antimicrobial agents and chemotherapy, 55(11), 5073-5077. doi:10.1128/AAC.05130-1189.

Pasman L (2012). The complication of coinfection. The Yale Journal of Biology and Medicine, 85(1), 127-132.

Patel P, Borkowf CB, Brooks JT, Lasry A (2014). Estimating per-act HIV transmission risk: a systematic review. AIDS, 28(10), 1509-1519. doi: 10.1097/QAD.ooooooooooooo298

Paton N, Sangeetha S, Earnest A, Bellamy R (2006). The impact of Malnutrition on Survival and The CD4 Count Response in HIV-infected Patients 
Journal of Epidemiology and Public Health (2019), 4(3): 138-155

https://doi.org/10.26911/jepublichealth.2019.04.03.01

Starting Antiretroviral Therapy. HIV Medicine, 323-330.

Pinkevych M, Petravic J, Chelimo K, Kazura JW, Moormann AM, Davenport MP (2012). The dynamic of naturally acquired immunity to plasmodium falciparum infection. PLOS Computational Biology, 8, 1-9. doi: 10.1371/journal.pcbi.1002729

Polyak CS, Yuhas K, Singa B, Khaemba M, Walson J, Richardson BA, John-Stewart G (2016). Cotrimoxazole Prophylaxis Discontinuation among Antiretroviral-Treated HIV-1 infected Adults in Kenya: A Randomized Noninferiority Trial. PLOS Medicine, 13(1): 1-16. doi: 10.1371/journal.pmed.1001934

Poudel AN, Newlands D, Simkhada P (2017). The Economic burden of HIV/ AIDS on individuals and households in Nepal: a quantitative study. BMC Health Service Research, 17, 76-89. doi:10.1186/s12913-017-1976-y

Rattanapunya S, Kuesap J, Chaijaroenkul W, Rueangweerayut R, Na-Bangchang $K$ (2015). Prevalence of malaria and HIV co-infection and influence of HIV infection on malaria disease severity in population residing in malaria endemic along the Thai-Myanmar border. Acta Tropica, 145, 55-60. http//dx.doi.org/10.1016/j.actatropic a.2015.02.001

Ruelas DS, Greene WC (2013). An integrated overview of HIV-1 Latency. Cell Biology, 155, 519-529. doi: https://dx.doi.org/10.1016\%2Fj.cell.2013.09. 044.

Sanyaolu A, Fagbenro-Beyioku A, Oyibo W, Badaru O, Onyeabor O, Nnaemeka C (2013). Malaria and HIV coinfection and their effect on haemoglobin levels from three health-care institutions in Lagos, Southwest Nigeria. African
Health Sciences, 13(2), 295-300. doi: 10.4314/ahs.v13i2.14

Saracino A, Nacarapa EA, Massinga EA, Martinelli D, Scacchetti M, Oliviera C (2012). Prevalence and clinical features of HIV and malaria co-infection in hospitalized adults in Beira, Mozambique. Malaria Journal, 11: 241-249. doi:10.1186/1475-2875-11-241

Sintasath DM, et al. (2005). Malaria prevalence and associated risk factors in Eritrea. American Journal of Tropical Medicine and Hygiene. doi: 10.4269/ajtmh.2005.72.682.

Skinner-Adams T, MacCarthy J, Gardiner D, Andrews K (2008). HIV and malaria co-infection: interactions and consequences of chemotherapy. Trends in Parasitology, 24, 264-271. doi: 10.1016/j.pt.2008.03.008.

Stratton SE, Watstein SB (2003). The Encyclopedia of HIV and AIDS second edition. New York: Facts On File, Inc.

Sunguya BF, et al. (2017). High magnitude of under nutrition among HIV infected adults who have not started ART in Tanzania-a call to include nutrition care and treatment in the test and treat model. BMC Nutrition, 3(1): 58. doi: 10.1186/s40795-017-0180-0.

Swaminathan S, et al. (2008). Nutritional status of persons with HIV infection, persons with HIV infection and tuberculosis, and HIV-negative individuals from Southern India. Clinical Infectious Diseases, 46(6): 946-949. Available at: http://dx.doi.org/10.1086/528860 .

Thiébaut R, et al. (2000). Lipodystrophy, metabolic disorders, and human immunodeficiency virus infection: Aquitaine Cohort, France, 1999. Clin Infect Dis. doi: 10.1086/317477.

Verhoeff FH, Brabin BJ, Hart CA, Chimsuku L, Kazembe P, Broadhead RL 
(1999). Increased Prevalence of Malaria in HIV-Infected Pregnant Women and Its Implications for Malaria Control. Tropical Medicine \& International Health, 4: 5-12. doi:10.1046/j.13653156.1999.00349.x

Wandeler G, Johnson LF, Egger M (2016). Trends in life expectancy of HIV-positive adults on ART across the globe: comparisons with general population. Current Opinion in HIV and AIDS, 11(5), 492-500. doi: 10.1097/COH.oo00000000000298

Watstein SB, Stratton SE (2003). The Encyclopedia of HIV and AIDS. New York: Facts On File, Inc.

Weiser SD, Young SL, Cohen CR, Kushel MB, Tsai AC, Tien PC, Hatcher AM, Frongillo EA, et al. (2011). Conceptual framework for understanding the bidirectional links between food insecurity and HIV/AIDS. The American journal of clinical nutrition, 94(6), $1729 \mathrm{~S}-1739 \mathrm{~S}$.

Whiteside A (2008). HIV/AIDS: a Very Short Introduction. New York: Oxford University Press.
WHO (2005). Interim WHO Clinical Staging of HIV/AIDS and HIV/AIDS case definitions for Surveillance. African Region.

(2010). How to integrated water, sanitation and hygiene into HIV programmes. Switzerland: USAID.

(2017). Malaria: Fact Sheet. Retrieved from http://www.who.int/mediacentre/factsheets/fso94/en/.

Yé Y, Louis VR, Simboro S, Sauerborn R (2007). Effect of meteorological factors on clinical malaria risk among children: an assessment using villagebased meteorological stations and community-based parasitological survey. BMC public health, 7: 101. doi: 10.1186/1471-2458-7-101

Zheng X, Lin M, Xie DD, Li J, Chen JT, Eyi UM, et al. (2017). Prevalence of HIV and Malaria: a Cross-Sectional Study on Bioko Island, Equatorial Guinea. African Journal of AIDS Research, 16(1), 65-70. doi: 10.2989/16085906.2016 .1257495 